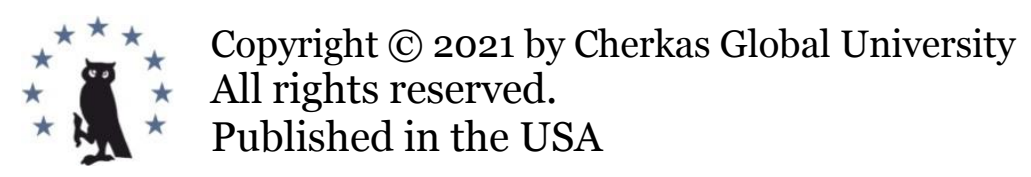

European Journal of Contemporary Education

E-ISSN 2305-6746

2021. 10(4): 1077-1082

DOI: 10.13187/ejced.2021.4.1077

https://ejce.cherkasgu.press

IMPORTANT NOTICE! Any copying, reproduction, distribution, republication (in whole or in part), or otherwise commercial use of this work in violation of the author(s) rights will be prosecuted in accordance with international law. The use of hyperlinks to the work will not be considered copyright infringement.

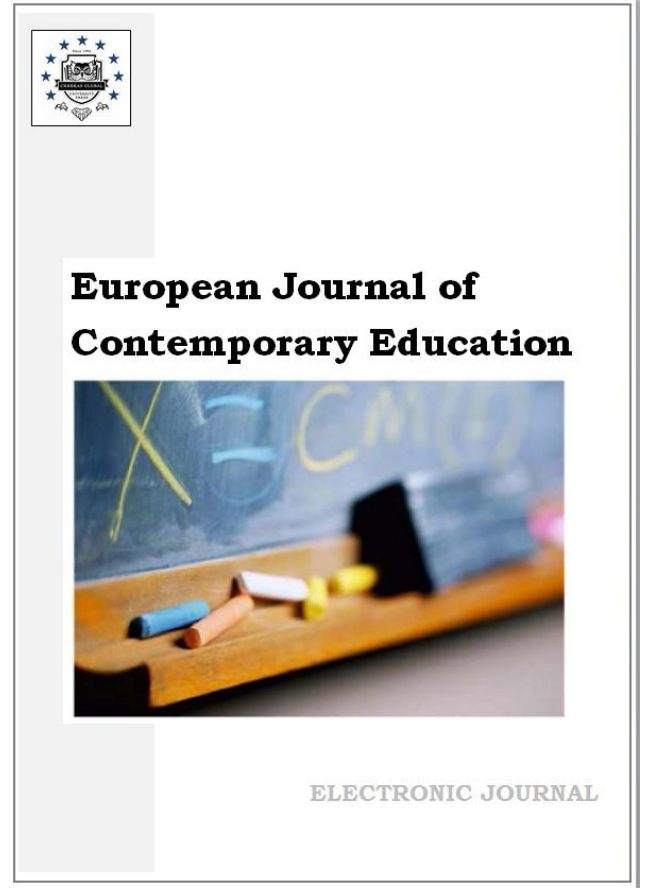

\title{
A History of Cherkas Global University: Its Making (1992-2014)
}

\author{
Konstantin V. Taran a, b, *
}

${ }^{a}$ Cherkas Global University, Washington, DC, USA

b Volgograd State University, Volgograd, Russian Federation

\begin{abstract}
This paper examines the history of the making of Cherkas Global University in the period 1992-2014. It shares the findings from an analysis of materials from the Vestnik Leib-Gvardii ('The Bulletin of the Leib Guard') newspaper reflecting the historical enlightenment and pedagogical activity of the university's founder published in the 1990s. A significant source used in putting this work together was Vestnik Leib-Gvardii's issues spanning 1992-1997, which contain information on the organization and conduct of classes across the academic disciplines taught to the student body. Another important source used was relevant materials of private origin, more specifically an interview with Professor Aleksandr Arvelodovich Cherkasov, the university's founder. In terms of methodology, use was made of the chronological method, which helped examine the study's topic in chronological sequence and reconstruct a coherent picture of the steps taken in educating youth and organizing historical-enlightenment activity. In addition, the content-analysis method was used to explore, inter alia, relevant materials from the periodical press. The author's conclusion is that August 1, 1992, can be considered the date of the foundation of both the Cherkas Global University Press academic publishing house, given the release of the first issue of the Vestnik Leib-Gvardii newspaper, and the actual research university, Cherkas Global University, as that is when the relevant historical-enlightenment activity and preparations for the establishment of the Cadet Platoon military academic unit began.
\end{abstract}

Keywords: Cherkas Global University, history of a university, Cadet Class, Vestnik LeibGvardii newspaper, instructional aids.

\footnotetext{
* Corresponding author

E-mail addresses: taran.constantin@yandex.ru (K.V. Taran)
} 


\section{Introduction}

On March 1, 2021, the International Network Center for Fundamental and Applied Research was reorganized into the private research organization Cherkas Global University. As a result, the related research establishments (Laboratory for World Civilizations, Laboratory for Professional and Pedagogical Training, Research Information Department, and Academic Publishing House Researcher s.r.o.) were merged into a single organization. Shortly later, the university's fundamental electronic library was established as well. As early as the fall of 2021, the library numbered over 60,000 items.

The creation of Cherkas Global University was preceded by years of painstaking work on the part of its founder, Aleksandr Cherkasov, a Doctor of Historical Science. This work began back in 1992.

\section{Materials and methods}

A significant source used in putting this work together was the Vestnik Leib-Gvardii newspaper's issues spanning 1992-1997, containing information on the organization and conduct of classes across the academic disciplines taught to the student body. Another important source was relevant materials of private origin, specifically an interview with Professor Aleksandr Cherkasov, the university's founder.

In terms of methodology, use was made of the chronological method, which helped examine the study's topic in chronological sequence and reconstruct a coherent picture of the steps taken in educating youth and organizing historical-enlightenment activity. In addition, use was also made of the content-analysis method in order to explore, inter alia, relevant materials from the periodical press.

\section{Discussion}

The historiography on the subject is rather limited. The monthly newspaper, Vestnik LeibGvardii was drawn upon in putting this work together, has already been the subject of research. Specifically, as a historical source, this newspaper has been explored by researcher G. Rajovic (Rajović, 2021). Today, the launch of Vestnik Leib-Gvardii in 1992 is associated with the date of the foundation of Cherkas Global University Press (for more information on the history of this academic publishing house, visit https://cherkasgu.press/info/about-publishing-house.html).

Other noteworthy publications in this context include an article by V.V. Tarakanov and S.D. Ludwig dedicated to the $20^{\text {th }}$ anniversary of A.A. Cherkasov's research and pedagogical activity (Tarakanov, Ludwig, 2019). The work examines the scholar's activity in the period 1999-2019. Upon graduation from university in 1999, Mr. Cherkasov was immediately invited to work in the Department of National History at Sochi State University for Tourism and Recreation (Sochi, Russian Federation). At Sochi State University, Mr. Cherkasov worked his way from being an instructor's assistant in 1999 to reaching the rank of Prorector for Research and Innovation in 2013.

That same year, 2019, scholars V.V. Tarakanov and M.A. Ponomareva released a work entitled 'INCFAR: Characteristics and Challenges (A Fifth Anniversary Tribute)' (Tarakanov, Ponomareva, 2019), in which an attempt was made to analyze the activity of the International Network Center for Fundamental and Applied Research in the first five years of its operation.

In 2006, A.A. Cherkasov set up a student research club called 'Historical Local Studies' at the Department of National History, which would turn into a student research laboratory. This subject has been explored by a team of researchers led by I.A. Ermachkov (Ermachkov et al., 2018).

In 2021, an article by A.Yu. Peretyatko entitled 'New Trends in the Organization of Historical Research in the South of Russia: A.A. Cherkasov's Activities in the Study of Slavery' was published in the journal Voprosy Istorii (Peretyatko, 2021). The article provides an analysis of the activities of Academic Publishing House Researcher s.r.o., the largest center for historical research in the south of Russia, and the role of A.A. Cherkasov, its head, in the study of slavery in the Caucasus.

Thus, A.A. Cherkasov's activity has attracted the attention of researchers across a variety of areas, including publication of newspapers and magazines, organization of research, and establishment of research institutions. Chronologically, this period spans the 1990s, 2000s, and 2010s. His 1990 activity has been researched relatively superficially. The purpose of the present study is to fill this specific gap. 


\section{Results}

So how did it all start? In 1992, that is a year after the disintegration of the Soviet Union, A.A. Cherkasov established the Semyonovsky Leib Guard Regiment military historical organization in the city of Sochi. Simultaneously, a monthly newspaper named Vestnik Leib-Gvardii was created as the organization's mouthpiece. It would go on to become the primary source used in restoring a complete picture of the pedagogical and scholarly-enlightenment process within the organization.

The establishment of the Semyonovsky Leib Guard Regiment military historical organization in 1992 was associated with the pursuit of an enlightenment agenda, with a focus on drawing more attention to Russia's prerevolutionary history, army, and navy. The first most accessible means of conducting enlightenment work through this organization was the use of a periodical of its own. The fourth issue of the newspaper carried a short piece on World War I's Brusilov Offensive (Pokhodnye stroki..., 1992: 2-3). The same issue also carried a piece on cadet corps, all-boys military educational institutions in Imperial Russia (Kadetskie korpusa, 1992: 3). Apparently, the piece came out for a reason, for as early as January 1993, pursuant to Directive No. 32/02 of January 28, 1993, signed by Cherkasov, Sochi became home to a Cadet platoon (academic unit) composed of two sections - cavalry and infantry. Pursuant to this document, the Cadet Platoon could be joined by boys ages 10-14. The document also noted the Cadet Platoon being a military educational institution with a commitment to "nurture in one a love of God, the Tsar, and the Motherland" (Prikaz № 32/o2, 1993: 1).

Classes for Cadet Platoon students began as early as February 27, 1993. This became known from a short piece entitled 'Information on the Cadet Platoon' (Informatsiya, 1993: 2). As recalled by A.A. Cherkasov, the Cadet Platoon recruited nine individuals, all of whom were enrolled in the cavalry section. The cadets underwent their cavalry training at the Kentavr horse riding school (Khostinsky District, Sochi). The training was paid for by Mr. Cherkasov personally (Vospominaniya o sluzhbe // Lichnyi arkhiv A.A. Cherkasova). There is a photo from that period showing A.A. Cherkasov at the school (Figure 1). The piece stated that on March 27, 1993, a monthlong training program for the Cadet Platoon ended, with two individuals qualifying for further study (Informatsiya..., 1993: 2). The Cadet Platoon did not exist for long due to lack of funding. Nevertheless, the effort put in with the Cadet Platoon in 1993 was the first attempt to achieve a continuous educational process.

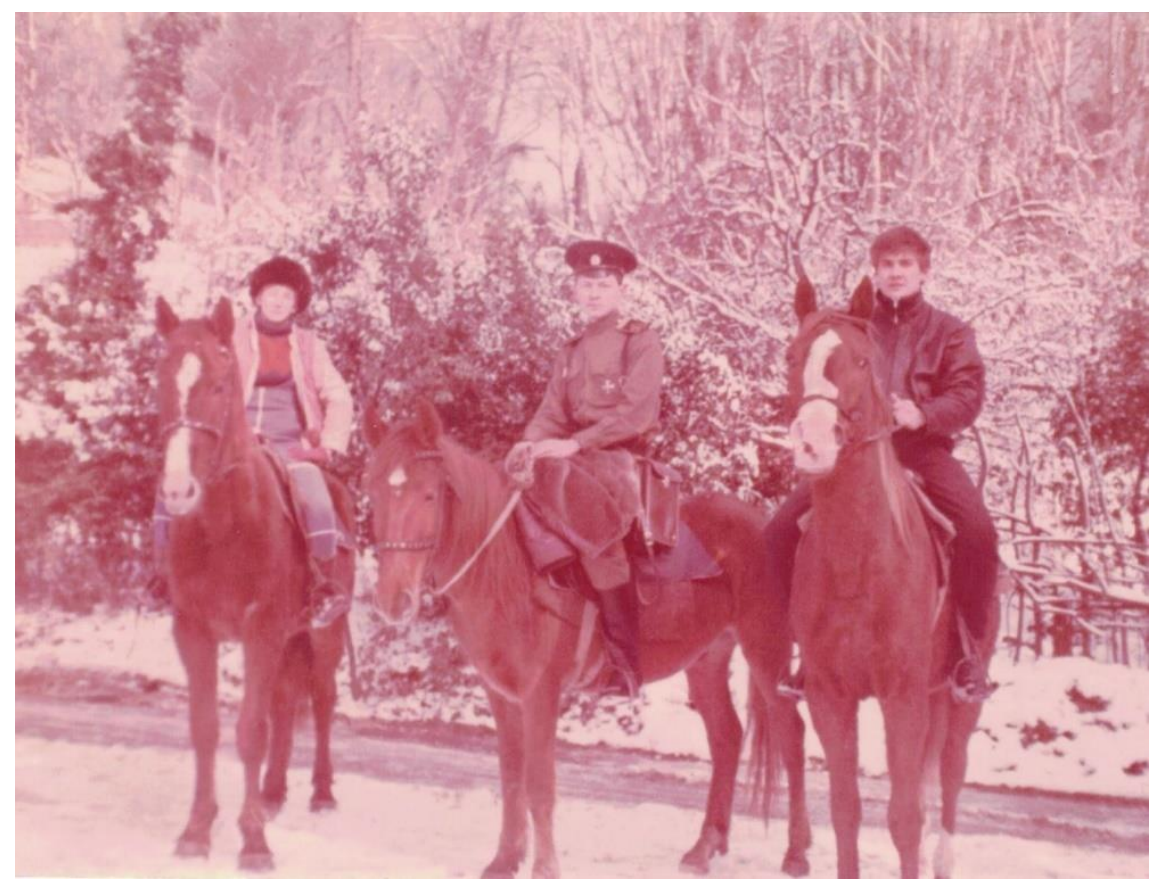

Fig. 1. A.A. Cherkasov (middle) at the "Kentavr" horse riding school (December 1992). On the left is V.A. Revonenko, the director of "Kentavr" 
Mr. Cherkasov resumed his education organization activity in December 1996. As stated in a piece entitled 'The District's Workdays and Holidays', a theoretical course was launched in the organization on December 8, 1996 (Budni i prazdniki okruga, 1996: 2). The course was aimed at enabling students to "learn all about relevant ranks, uniforms, regulations, arms, and so on". According to the author of the piece, "efforts to set up a course of this kind were undertaken in Sochi four years ago, when there was in operation the Cadet [Platoon], but the idea has materialized only now" (Budni i prazdniki okruga, 1996: 2).

Classroom instruction within the organization was accompanied by field trips. Specifically, from October to December 1996 three field trips were undertaken, with two of them being to the Semyonovsky Spire mountain. Such field trips consisted of classes involving the use of impact munitions, hand-to-hand combat, and firearms training (Budni i prazdniki okruga, 1996: 2). Based on a plan recommended by the Staff, classes were scheduled as follows: 2-4 times per week - handto-hand combat; 1-2 times per week - theoretical classes; 1-2 times per month - field trips; Sundays - group visits to the church (Obrashchenie ..., 1996: 3).

A piece entitled 'Sochi Military Garrison Theoretical Course', published in the newspaper's $11^{\text {th }}$ issue (January 1997), stated that in the previous month 11 classes were held. The training system was based on lectures and tests. Students attending the course were to develop knowledge of the various ranks in the regiment and the appearance of members of the lower and upper ranks, including shoulder marks, combat and dress uniforms, and cold weather gear. In terms of firearms, students were to acquire knowledge of the tactical/technical characteristics of the Makarov pistol and its essential components and learn to disassemble and reassemble it (Teoreticheskii kurs SVG, 1997 2: 1-2). There is a newspaper photo illustrating the teaching of this theoretical course (Figure 2).

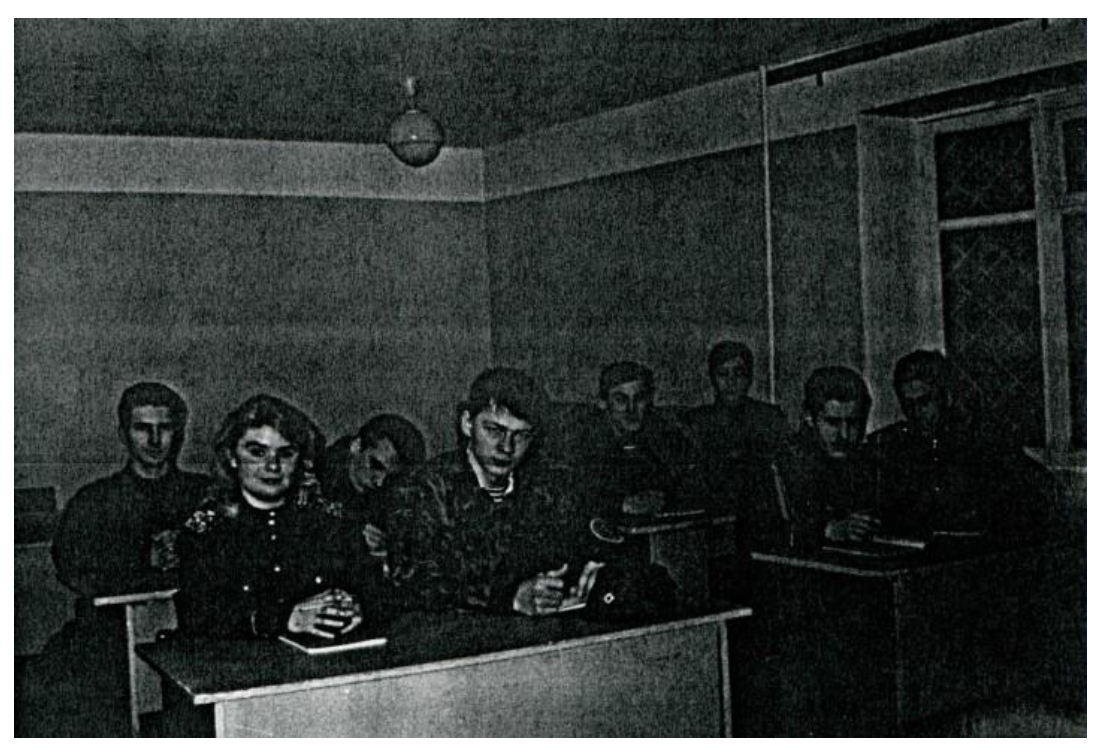

Fig. 2. Students attending a class in Sochi Military Garrison Theoretical Course (Vestnik Leib-Gvardii, 1997: 2)

That the conduct of classes in the theoretical course continued was announced in the next, $12^{\text {th }}$, issue of the newspaper: "Instruction in the theoretical course continues. Students attend handto-hand combat classes involving the use of impact munitions. Intensive firearms training has begun too" (Budni i prazdniki okruga, 1997: 2). Instruction in the theoretical course would continue to be provided, as evidenced in the newspaper's $13^{\text {th }}$ issue (March 1997) (Budni i prazdniki okruga, 1997a: 3).

The $13^{\text {th }}$ issue of the newspaper carried, under the section 'Historical Angle', a piece on military schools in the Russian Empire (Istoricheskii rakurs, 1997: 3). The piece furnished data on the number and types of military schools and their student body and provided the mottos of different military schools. In the $14^{\text {th }}$ issue, under the same section, insight was provided into Cadet corps, the educational process, academic disciplines, and other characteristics of education in those schools (Istoricheskii rakurs, 1997a: 3). 
It would be unfair not to say a few words about academic/instructional activity of said military historical organization. Back on the eve of the introduction of the theoretical course, in 1995, A.A. Cherkasov and A.B. Sabanov drew up a document containing a set of recommended practices for the purpose, 'Recommended Practices for Senior Staff within the Divisions of the District Electoral Commission' (Istoricheskii rakurs..., 1995). Parts of the document were published in the $1^{\text {th }}$ issue of the newspaper (Obyazannosti voinskikh chinov, 1997: 3).

Overall, 14 issues of the Vestnik Leib-Gvardii newspaper were released, with the last issue being released as a combined one (for both April and May) in 1997. Due to A.A. Cherkasov taking another job, the base for the conduct of the theoretical course was dismantled, leading to discontinuation of the educational process. In 1999, Mr. Cherkasov took up work at the university.

Thus, during the $1990 \mathrm{~s}$ Mr. Cherkasov not only was involved in the production of a periodical that would go on to become the first stone in the foundation of a university's publishing house but was also engaged in educational and enlightenment activity as part of a military historical organization. The first issue of the Vestnik Leib-Gvardii newspaper was published in August 1992. While the release date was not specified in the newspaper, August 1 can be considered today the date of its creation. In other words, the date of the creation of Cherkas Global University Press is August 1, 1992. The newspaper became an important tool for conducting enlightenment work, a sort of bullhorn for the organization, which almost immediately addressed itself to advancing the cause of educating youth and developing the pedagogical process. Consequently, August 1, 1992 can be considered the date of the foundation of Cherkas Global University as well, despite the fact that the first Cadet class was formed only a few months later, in January 1993.

Starting in 1999, Mr. Cherkasov worked at the university. In 2002, he successfully defended his candidate's dissertation, and in 2006, he assumed charge of the Department of National History, where he immediately set up a student research club called 'Historical Local Studies'. Over the course of the following six years, this research club had 24 student members, who delivered nearly 200 reports at various conferences, round tables, and meetings. Members of the club took an active part in two conferences organized by A.A. Cherkasov, 'The Humanities: Research into and Methodology for Teaching Them in College' and 'Greater Sochi in the Past and in the Future'. The club remained in operation until 2012, when it was disbanded due to discontinuation of admission to the program.

In 2007, A.A. Cherkasov successfully defended his doctoral dissertation to become a Doctor of Historical Science. Even as early as this point, Mr. Cherkasov put forth an initiative to establish a research institute at Sochi State University. However, the initiative was not proceeded with due to lack of funding. In 2014, following his departure from the university, Mr. Cherkasov created an establishment of his own - the International Network Center for Fundamental and Applied Research. The institution was reorganized in 2021 into Cherkas Global University.

\section{Conclusion}

August 1, 1992, can be considered the date of the foundation of both the Cherkas Global University Press academic publishing house, given the release of the first issue of the Vestnik LeibGvardii newspaper, and the actual research university, Cherkas Global University, as that is when the relevant historical-enlightenment activity and preparations for the establishment of the Cadet Platoon military academic unit began.

\section{References}

Budni i prazdniki okruga, 1996 - Budni i prazdniki okruga [Weekdays and holidays of the district]. Vestnik Leib-gvardii. 1996. 10: 2. [in Russian]

Budni i prazdniki okruga, 1997 - Budni i prazdniki okruga [Weekdays and holidays of the district]. Vestnik Leib-gvardii. 1997. 12: 2. [in Russian]

Budni i prazdniki okruga, 1997a - Budni i prazdniki okruga [Weekdays and holidays of the district]. Vestnik Leib-gvardii. 1997. 13: 3. [in Russian]

Ermachkov et al., 2018 - Ermachkov, I.A., Ekimov, A.I., Vazerova, A.G. (2018). Students' humanitarian science club activity in 2006-2012. European Journal of Contemporary Education. 7(2): 286-290.

Informatsiya..., 1993 - Informatsiya o kadetskom vzvode [The information about the cadet platoon]. Vestnik Leib-gvardii. 1993. 8: 2. [in Russian] 
Istoricheskii rakurs, 1997 - Istoricheskii rakurs [Historical perspective]. Vestnik Leibgvardii. 1997. 13: 3. [in Russian]

Istoricheskii rakurs, 1997a - Istoricheskii rakurs [Historical perspective]. Vestnik Leibgvardii. 1997. 14: 3. [in Russian]

Kadetskie korpusa, 1992 - Kadetskie korpusa [Cadet Corps]. Vestnik Leib-gvardii. 1992. 4: 3. [in Russian]

Lichnyi arkhiv A.A. Cherkasova - Lichnyi arkhiv A.A. Cherkasova [The personal archive of A.A. Cherkasov]. [in Russian]

Obrashchenie..., 1996 - Obrashchenie shtaba Yuzhno-rossiiskogo okruga k chastyam i predstavitel'stvam O.I.K. [Appeal of the headquarters of the South-Russian district to the units and representations of O.I.K.]. Vestnik Leib-gvardii. 1996. 10: 3. [in Russian]

Obyazannosti voinskikh chinov, 1997 - Obyazannosti voinskikh chinov [The Duties of military ranks]. Vestnik Leib-gvardii. 1997. 11: 3. [in Russian]

Peretyatko, 2021 - Peretyatko, A.Yu. (2021). Novye tendentsii v organizatsii istoricheskikh issledovanii na Yuge Rossii: deyatel'nost' A. A. Cherkasova po izucheniyu rabstva [New trends in the organization of historical research in the South of Russia: A. A. Cherkasov's activities in the study of slavery]. Voprosy istorii. 6(1): 274-287. [in Russian]

Pokhodnye stroki..., 1992 - Pokhodnye stroki Pervoi mirovoi voiny [The marching lines of the First World War]. Vestnik Leib-gvardii. 1992. 4: 2-3. [in Russian]

Prikaz № 32/02, 1993 - Prikaz № 32/o2 [Order No. 32/o2]. Vestnik Leib-gvardii. 1993. 6: 1. [in Russian]

Rajović, 2021 - Rajović, G. (2021). The Newspaper "Vestnik Leib-Gvardii" (1992-1997) as a Historical Source. Propaganda in the World and Local Conflicts. 8(2): 93-98. DOI: 10.13187/ pwlc.2021.2.93

Tarakanov, Ludwig, 2019 - Tarakanov, V.V., Ludwig, S.D. (2019). Aleksandr Cherkasov: A Scholar, Publisher, and Organizer of Research Collaborations (to the 20th Anniversary of the Scholar's Research and Pedagogical Activity). Bylye Gody. 53(3): 914-920.

Tarakanov, Ponomareva, 2019 - Tarakanov, V.V., Ponomareva, M.A. (2019). INCFAR: Characteristics and Challenges (A Fifth Anniversary Tribute). European Journal of Contemporary Education. 8(4): 984-992.

Teoreticheskii kurs SVG, 1997 - Teoreticheskii kurs SVG [Sochi military garrison theoretical course]. Vestnik Leib-gvardii. 1997. 11: 1-2. [in Russian]

V pomoshch'..., 1995 - V pomoshch' komandnomu sostavu podrazdelenii O.I.K. [In help of the commanding staff of O.I.K.]. Pod red. A.A. Cherkasova, A.B. Sabanova. 1-e izdanie. Sochi, 1995. [in Russian] 